\title{
Placental Transfer and Fetal Urinary Excretion of Gentamicin during Constant Rate Maternal Infusion
}

\author{
RALPH E. KAUFFMAN, ${ }^{(20)}$ JOHN A. MORRIS, AND DANIEL L. AZARNOFF \\ Clinical Pharmacology-Toxicology Center, Mental Retardation Research Center, Departments of Pediatrics, \\ Obstetrics and Gynecology, Medicine, and Pharmacology, University of Kansas Medical Center,
} Kansas City, Kansas, USA

\section{Extract}

Placental transfer and fetal urinary excretion of gentamicin was studied in midtrimester goat and human previable fetuses during constant rate maternal infusion with the drug. Gentamicin was not detected in the serum of any of the goat fetuses, even when maternal serum concentrations ranged from $15.2 \mu \mathrm{g} / \mathrm{ml}$ to $20.9 \mu \mathrm{g} / \mathrm{ml}$. However, gentamicin was present in the amniotic fluid of four animals. Gentamicin was also present in fetal urine collected from three animals. In contrast, human fetal central venous serum concentrations of gentamicin were $21-37 \%$ of those in maternal serum after constant rate infusion of the mother. In addition, gentamicin was present in human fetal urine in concentrations 2-3 times those in fetal serum. The observed difference in fetal serum concentration of gentamicin between the two species represents a difference in placental permeability to gentamicin and/or a difference in fetal renal clearance of the drug.

\section{Speculation}

This study illustrates the inherent danger in extrapolating information obtained from animal studies of placental transfer of drugs to human fetuses, and emphasizes the need to conduct carefully designed, confirmatory studies in human beings. Animal studies are necessary and useful, but information directly applicable to improved understanding and care of the human fetus must necessarily come from corroborative studies involving the human fetal-maternal unit.

Gentamicin, an aminoglycoside antibiotic used to treat gram-negative bacterial infections during gestation, may cause renal and eighth nerve toxicity if safe concentrations of the drug are exceeded (6). Hearing loss and abnormalities of vestibular function have been reported in children born of mothers who received streptomycin, a closely related antibiotic, during pregnancy $(3,4,11)$. Von Kobyletzki (8) and Yoshioka and associates (14) demonstrated the presence of gentamicin in cord venous blood of term neonates whose mothers received a single intramuscular injection of the drug before delivery. The present study was designed to investigate the degree of exposure of the human midtrimester fetus to gentamicin and the ability of the fetus to excrete gentamicin during constant rate intravenous infusion of the antibiotic into the mother. Significant differences in concentration of the drug in the human fetus as compared with the goat fetus are described.

\section{MATERIALS AND METHODS}

\section{BIOASSAY}

Gentamicin concentration in serum, urine, and amniotic fluid was measured using a disc agar diffusion microbiologic assay with Staphylococcus aureus ATCC 6538P as the test organism. One-half milliliter of a 2-hr culture of $S$. aureus in brain heart infusion broth, $4 \times 10^{7}$ organisms $/ \mathrm{ml}$, was added to $100 \mathrm{ml}$ Penassay seed agar (15) at $48^{\circ}$ after adjusting the agar $\mathrm{pH}$ to 7.0 with $0.1 \mathrm{ml} 10 \mathrm{~N}$ sodium hydroxide. Ten milliliters seeded agar were placed in each $100-\mathrm{mm}$ diameter petri dish and allowed to cool to room temperature. A $30-\mu 1$ aliquot of each specimen was placed on a 7-mm diameter Millipore filter disc which was placed on the seeded agar. Six discs were placed on each plate, including a $2.5 \mu \mathrm{g} / \mathrm{ml}$ internal standard. Plates were incubated at $37^{\circ}$ for $10 \mathrm{hr}$ and the diameter of the zone of inhibition measured under magnification on a dark field colony counter (16). Standards were made up in the appropriate biological fluid in concentrations of 10 , $5,2.5,1.25$, and $0.625 \mu \mathrm{g} / \mathrm{ml}$. All assays were run in quadruplicate. Maternal urine samples were diluted $1 / 2$ with $0.1 \mathrm{M}$ phosphate buffer $\mathrm{pH} 7.0$, before assay. Gentamicin concentration was computed from the standard curve based on a linear relation between the square of the diameter of the zone of bacterial growth inhibition and the log of the concentration of gentamicin. Reproducibility of the method was $\pm 10 \%$ at the concentrations measured.

\section{ANIMAL STUDIES}

Pregnant goats with known breeding dates were used. During general endotracheal anesthesia, using $0.5 \%$ halothane in a mixture of equal parts nitrous oxide and oxygen, the uterus was exposed through a midline abdominal incision. Using method described by Almond and associates (1) the fetal neck was identified by palpation and a purse string suture placed through the uterine wall and fetal skin. An incision was made within the boundary of the suture thereby exposing the fetal jugular vein. A no. 8 French polyethylene catheter was placed in the vein and advanced centrally $8-10 \mathrm{~cm}$ into the fetal heart to facilitate sampling of fetal mixed venous blood. A similar catheter was placed in the amnion. The incision was closed in layers and the catheters brought to the exterior of the maternal abdomen. In those experiments in which fetal urine was collected, an incision was made in the fetal suprapubic area, the dome of the fetal urinary bladder was identified, and a polyethylene catheter sutured into the bladder. Experiments were carried out $24 \mathrm{hr}$ after surgery by which time the animals had fully recovered from anesthesia. 
The dams were given an intravenous loading dose of 1,2 , or $3 \mathrm{mg}$ gentamicin/Kg followed by a 5 - or 6 - $\mathrm{hr}$ constant rate infusion based on an excretion rate constant of $0.231 \mathrm{hr}^{-1}$. Samples of maternal and fetal serum and amniotic fluid were obtained at $30 \mathrm{~min}$ and then hourly throughout the infusion. In those experiments in which fetal urine was collected, the total fetal urine output during the infusion was pooled. Fetal and maternal $\mathrm{P}_{\mathrm{O}_{2}}, \mathrm{P}_{\mathrm{CO}_{2}}$, and $\mathrm{pH}$ were measured before beginning and at 180 and $360 \mathrm{~min}$ during each experiment. Data were discarded from those experiments in which fatal blood gases indicated fetal distress or death.

\section{HUMAN STUDIES}

Six patients of 18-23 weeks of gestational age were studied. All patients were multiparous, and were scheduled for elective abortion-hysterectomy by physicians not involved in the project. After admission to the hospital, each patient was fully appraised of the study and signed informed consent was obtained. Two to $6 \mathrm{hr}$ before operation each patient received $80 \mathrm{mg}$ gentamicin iv followed by an intravenous infusion of $18.5 \mathrm{mg} / \mathrm{hr}$, based on a gentamicin elimination half-life in serum of $3 \mathrm{hr}$ (9). Maternal venous blood for gentamicin assay was obtained $30 \mathrm{~min}$ after the loading dose and hourly during the infusion period.

Using the method described by Morris and associates (10), the umbilical cord was exteriorized after hysterotomy with the patient under general anesthesia supplemented with halothane to enhance uterine relaxation. Amniotic fluid, cord venous, and maternal common iliac arterial blood samples were obtained; thereupon, the fetus was exteriorized and a central venous blood sample as well as a sample of fetal urine were obtained. The umbilical cord was clamped, cut, and the deadborn fetus was weighed, measured, and necropsied. With the completion of the abortion, a hysterectomy was then accomplished in the usual fashion. The time elapsed between start of the gentamicin infusion and obtaining each sample was recorded.

Gestational age was estimated from the mean growth curve for fetal age developed by Streeter (12). Fetal weights ranged from $238 \mathrm{~g}$ to $515 \mathrm{gm}$. Fetal crown to rump and crown to heal

Table 1. Fetal and maternal concentrations of gentamicin in four animals at 100 days' gestation given $2 \mathrm{mg} / \mathrm{kg}$ loading dose followed by 5-hr infusion at $0.46 \mathrm{mg} / \mathrm{kg} \mathrm{hr}^{-1}$

\begin{tabular}{ccccc}
\hline & $\begin{array}{c}\text { Maternal serum level } \\
\text { during infusion, } \\
\mu \mathrm{g} / \mathrm{ml}\end{array}$ & $\begin{array}{c}\text { Fetal } \\
\text { urine, } \\
\mu \mathrm{g} / \mathrm{ml}\end{array}$ & $\begin{array}{c}\text { Amnion, } \\
\mu \mathrm{g} / \mathrm{ml}\end{array}$ & $\begin{array}{c}\text { Fetal } \\
\text { serum, } \mu \mathrm{g} / \mathrm{ml}\end{array}$ \\
\cline { 2 - 5 } Animal & Mean (Range) & 0 & 0 & 0 \\
\hline 1 & $5.0(4.0-6.3)$ & 0 & 0 & 0 \\
2 & $6.4(5.3-7.1)$ & 0 & 0 & 0 \\
3 & $5.7(2.4-8.8)$ & 0 & 0 & 0 \\
4 & $4.9(4.5-5.4)$ & 0 & & \\
\hline
\end{tabular}

lengths ranged from $15 \mathrm{~cm}$ to $19 \mathrm{~cm}$ and $23 \mathrm{~cm}$ to $30 \mathrm{~cm}$, respectively. Placental weights ranged from $107 \mathrm{~g}$ to $240 \mathrm{~g}$.

\section{RESULTS}

\section{ANIMAL STUDIES}

The mean maternal serum concentrations of gentamicin in four animals which received $1 \mathrm{mg} / \mathrm{kg}$ ranged between 7.5 $\mu \mathrm{g} / \mathrm{ml}$ and $10.4 \mu \mathrm{g} / \mathrm{ml}$ during the infusion period. Mean maternal serum gentamicin concentrations in four animals which were given three $\mathrm{mg} / \mathrm{kg}$ varied between $15.2 \mu \mathrm{g} / \mathrm{ml}$ and $20.9 \mu \mathrm{g} / \mathrm{ml}$. A detectable level of gentamicin was not achieved in fetal serum in any of these experiments, even in the presence of high maternal serum concentrations. However, gentamicin was present in amniotic fluid obtained from two animals receiving $1 \mathrm{mg} / \mathrm{kg}$ and two animals receiving $3 \mathrm{mg} / \mathrm{kg}$ from which fetal urine was not collected.

Fetal urine was obtained from four animals of 100 days of gestational age which received $2 \mathrm{mg}$ gentamicin $/ \mathrm{kg}$ (Table 1 ). Maternal mean serum concentrations ranged from 4.9 to 6.4 $\mu \mathrm{g} / \mathrm{ml}$. Gentamicin was not present in detectable concentration in fetal serum, fetal urine, or amniotic fluid in any of these animals.

Fetal urine was collected from three animals of 120 days of gestational age. One animal received $3 \mathrm{mg}$ gentamicin $/ \mathrm{kg}$, one animal received $2 \mathrm{mg} / \mathrm{kg}$, and one animal received $1 \mathrm{mg} / \mathrm{kg}$ (Table 2). Corresponding maternal mean serum levels were $25.6 \mu \mathrm{g} / \mathrm{ml}, 15.0 \mu \mathrm{g} / \mathrm{ml}$, and $7.4 \mu \mathrm{g} / \mathrm{ml}$, respectively. Gentamicin was not detected in fetal serum nor amniotic fluid of any of the animals. However, gentamicin was present in fetal urine from all three animals in concentrations directly proportional to maternal serum concentrations (Table 2), which indicated placental transfer of the drug even though detectable concentrations were absent in fetal serum.

\section{HUMAN STUDIES}

Mean serum concentrations of gentamicin in gravid women receiving a loading dose of $80 \mathrm{mg}$ followed by an infusion at $18.5 \mathrm{mg} / \mathrm{hr}$ ranged from $2.1 \mu \mathrm{g} / \mathrm{ml}$ to $6.2 \mu \mathrm{g} / \mathrm{ml}$. The variation in serum concentration probably reflects differences in body weight and renal clearance of gentamicin between individual patients. In contrast to the goat fetuses, gentamicin was present in human fetal central venous serum and cord venous serum in all cases (Table 3). Fetal central venous serum concentrations of gentamicin were $21-37 \%$ of those in maternal serum. Gentamicin concentration in cord venous serum closely paralleled that in central venous serum in all instances, which indicated equilibration at the time of sampling.

Gentamicin appeared in human fetal urine in concentrations 2-3 times those in fetal serum, which demonstrated the ability of the midtrimester fetal kidney to concentrate and excrete the drug. Amniotic fluid did not contain detectable amounts of gentamicin. Presumably, the fetus did not void during the infusion period. As expected, the antibiotic was present in high concentration in maternal urine.

Table 2. Fetal and maternal concentrations of gentamicin in three animals at 120 days' gestation during 5-hr infusion

\begin{tabular}{|c|c|c|c|c|c|c|}
\hline \multirow[b]{2}{*}{ Animal } & \multirow{2}{*}{$\begin{array}{c}\text { Loading } \\
\text { dose, } \mathrm{mg} / \mathrm{kg}\end{array}$} & \multirow{2}{*}{$\begin{array}{c}\text { Infusion rate, } \\
\mathrm{mg} / \mathrm{kg} \mathrm{hr}^{-1}\end{array}$} & $\begin{array}{c}\text { Maternal serum level } \\
\text { during infusion, } \mu \mathrm{g} / \mathrm{ml}\end{array}$ & \multirow[b]{2}{*}{ Fetal urine, $\mu \mathrm{g} / \mathrm{ml}$} & \multirow[b]{2}{*}{ Amnion, $\mu \mathrm{g} / \mathrm{ml}$} & \multirow[b]{2}{*}{ Fetal serum, $\mu \mathrm{g} / \mathrm{ml}$} \\
\hline & & & Mean (Range) & & & \\
\hline 1 & 3 & 0.69 & $25.6(12.0-33.0)$ & 4.0 & 0 & 0 \\
\hline 2 & 2 & 0.46 & $15.0(12.9-19.0)$ & 1.4 & 0 & 0 \\
\hline 3 & 1 & 0.23 & $7.4(5.7-10.0)$ & 0.9 & 0 & 0 \\
\hline
\end{tabular}


Table 3. Human midtrimester fetus ${ }^{1}$

\begin{tabular}{|c|c|c|c|c|c|c|c|}
\hline \multirow[b]{2}{*}{ Patient } & \multirow{2}{*}{$\begin{array}{l}\text { Infusion } \\
\text { time, min }\end{array}$} & \multirow{2}{*}{$\begin{array}{c}\text { Maternal serum level } \\
\text { during infusion, } \mu \mathrm{g} / \mathrm{ml}\end{array}$} & \multirow{2}{*}{$\begin{array}{c}\text { Fetal } \\
\text { serum, } \mu \mathrm{g} / \mathrm{ml}\end{array}$} & \multirow{2}{*}{$\begin{array}{c}\text { Cord } \\
\text { serum, } \mu \mathrm{g} / \mathrm{ml}\end{array}$} & \multirow{2}{*}{$\begin{array}{c}\text { Fetal } \\
\text { urine, } \mu \mathrm{g} / \mathrm{ml}\end{array}$} & \multirow[b]{2}{*}{ Amnion, $\mu \mathrm{g} / \mathrm{ml}$} & \multirow{2}{*}{$\begin{array}{c}\text { Maternal } \\
\text { urine, } \mu \mathrm{g} / \mathrm{ml}\end{array}$} \\
\hline & & & & & & & \\
\hline 1 & 140 & $4.1(3.5-4.7)$ & 1.3 & 1.1 & 3.5 & 0 & 440 \\
\hline 2 & 150 & $6.2(5.1-6.9)$ & 1.3 & 1.2 & 2.8 & 0 & 83 \\
\hline 3 & 200 & $3.8(2.8-4.3)$ & 0.9 & 1.1 & 2.8 & 0 & 292 \\
\hline 4 & 300 & $3.1(2.3-3.7)$ & 0.9 & 1.0 & 1.9 & 0 & 450 \\
\hline 5 & 308 & $3.8(2.5-5.5)$ & 1.4 & 1.5 & 2.8 & 0 & 920 \\
\hline 6 & 350 & $2.1(1.3-2.5)$ & 0.5 & 0.6 & 2.5 & 0 & 320 \\
\hline
\end{tabular}

${ }^{1}$ Mother given $80 \mathrm{mg}$ loading dose of gentamicin followed by infusion at $18.5 \mathrm{mg} / \mathrm{hr}$.

\section{DISCUSSION}

Placental transfer of gentamicin across the goat placenta could not be demonstrated by detection of the drug in fetal serum. Placental passage was demonstrated, however, by finding the drug in amniotic fluid or concentrated in fetal urine. Furthermore, gentamicin was present in amniotic fluid only when fetal urine was not collected throughout the sampling period. This indicates the source of gentamicin in amniotic fluid was voided fetal urine.

The presence of gentamicin in urine of goat fetuses of 120 days gestation and absence of drug in urine of 100-day-old fetus suggests that placental permability to gentamicin increases as fetal age advances. This is consistent with the decrease in thickness of the tissue layers interposed between the fetal and maternal circulations which is known to occur as gestation progresses (13).

The partition of gentamicin between human maternal and midtrimester fetal serum observed in this study is similar to that reported in term infants by Yoshioka (14). In addition, we have demonstrated the ability of the midtrimester fetal kidney to concentrate and excrete the drug. Concentration of tobramycin, an antibiotic which is structurally related to gentamicin, by the human midtrimester fetal kidney has been reported recently (2).

When the maternal level of gentamicin is maintained in the therapeutic range, the serum concentrations observed in the human fetus are well below those associated with eighth nerve and inner ear damage in the mature organism, which leads one to assume that the chance of producing toxicity in the fetus is quite remote. However, an unanswered question at the present time is whether or not at certain times during gestation the developing organism may be susceptible to toxicity from a lower concentration of gentamicin than that producing damage in the mature individual. The concentration in the fetus is probably adequate to provide antimicrobial activity against many of the organisms for which gentamicin may be used.

An important finding in this study is the striking difference between the animal model and the human being with respect to fetal central venous serum concentration of gentamicin. In contrast to the goat fetus, the antibiotic reached clinically significant concentrations in human fetal serum and urine when therapeutic concentrations were maintained in maternal serum.

Assuming there is no significant difference in renal clearance of gentamicin between the goat fetus and human fetus, this observation represents a significant difference between the two species with respect to placental permeability to gentamicin. Although placental physiology does not always correlate with variations in anatomy of that organ, a difference in placental transfer of gentamicin is consistent with known gross anatomic and histologic differences between the goat and human placenta (5). A recently reported study of placental transfer of penicillin $\mathrm{G}$ in goats also does not correlate well with earlier studies of placental transfer of penicillin in human fetuses at term (7).

The observed species differences in fetal serum concentration of gentamicin could also be due, at least in part, to greater renal clearance of gentamicin in the goat fetus as compared with the human fetus. Since the fetal renal clearance of gentamicin cannot be calculated for either species from the available data, the comparative influence of fetal renal clearance on fetal gentamicin concentrations cannot be determined. The acquisition of this type of information from the human fetus would be virtually impossible for technical as well as ethical reasons.

This study illustrates the danger inherent in extrapolating information obtained from animal models, and emphasizes the need to conduct carefully designed, confirmatory studies in human beings. Many different animal models have been and are presently being used to study placental transfer of a variety of drugs. Animal studies are necessary and useful. However, information directly applicable to improved understanding and care of the human fetus must necessarily come from corroborative studies involving the human retal-malurnal uni.

\section{SUMMARY}

Gentamicin was present in midtrimester human fetal central venous blood, umbilical vein blood, and fetal urine after constant rate intravenous infusion of the antibiotic into the mother before elective abortion-hysterectomy. In contrast, no gentamicin was found in midtrimester fetal goat central venous blood after intravenous infusion of the pregnant goat with gentamicin. However, gentamicin was found in fetal goat urine and amniotic fluid, which indicates placental transfer did occur. The implications of the observed species differences are discussed.

\section{REFERENCES AND NOTES}

1. Almond, C. H., Boulos, B. M., Davis, L. E., and McKenzie, J. M.: New surgical technique for studying placental transfer of drugs in vivo. J. Surg. Res., 10: 7 (1970).

2. Bernard, B., Garcia, S. J., Ballard, C. A., Ivler, D., Thrupp, L. D., Mathies, A. W., and Wehrle, P. F.: Tobramycin: Maternal-fetal pharmacology (Abstract). Pediat. Res., 7: 318/90 (1973).

3. Bolletti, M., and Croatto, L.: Deafness in a five year old girl resulting from streptomycin therapy during pregnancy. Acta Paediat. Latina, 11: 1 (1958).

4. Conway, N., and Birt, B. D.: Streptomycin in pregnancy: Effect on the foetal ear. Brit. Med. J., 2: (1965).

5. Dawes, G. S.: Foetal and Neonatal Physiology: A Comparative Study of the Changes at Birth, pp. 26, 27 (Yearbook Medical Publishers, Chicago, 1968).

6. Jackson, G. G., and Arcieri, G.: Ototoxicity of gentamicin in man: A survey and controlled analysis of clinical experience in the United States. J. Infect. Dis., 124: S130 (1971).

7. Kauffman, R. E., Boulos, B. M., and Azarnoff, D. L.: Placental transfer of penicillin $\mathrm{G}$ during constant-rate infusion in the goat. Amer. J. Obstet. Gynecol., 117: (1973). 
8. Kobyletzke, von D.: Ubertritt und elimination von präpratal dem neugeborenen zugeführten medikamenten. Monatsschr. Kinderheild., 116: 250 (1968).

9. McHenry, M. C., Gavan, T. L., Gifford, R. W., Jr., Geurkink, N. A., Van Ammen, R. A., Town, M. A., and Wagner, J. G.: Adjustments based on endogenous creatinine clearance and serum creatinine concentration. Ann. Int. Med., 74: 192 (1971).

10. Morris, J. A., Hustead, R. F., Robinson, R. G., and Haswell, G. L.: Measurement of feto-placental blood volume in the human previable fetus. Amer. J. Obstet. Gynecol., 118: 927 (1974).

11. Rebattu, J. P., Lesue, G., and Megard, M.: Streptomy cine, barriere placentaire troubles cochleo-vestibularies. J. Franc. Otorhinolaryngol., 9: 411 (1960).

12. Streeter, G. L.: Weight, sitting height, head size, foot length, and menstrual age of the human embryo. Contrib. Embryol. Inst., II: 143 (1921).

13. Wynn, R. M.: Morphology of the placenta. In: N.S. Assalii: Biology of Gestation, p. 103 (Academic Press, New York, 1968).
14. Yoshioka, H., Monma, T., and Matsuda, S.: Placental transfer of gentamicin. J. Pediat., 80: 121 (1972).

15. Difco Labs, Detroit, Mich.

16. American Optical Corp., Scientific Instrument Division, Buffalo, N.Y.

17. The authors wish to express their appreciation to Ms. Patricia Ludwig for her expert technical assistance.

18. This work was supported by United States Public Health Service Grants nos. GM 15956 and HD 02528.

19. The present address of Dr. J. A. Morris is: Department of Obstetrics and Gynecology, Charles R. Drew Postgraduate Medical School, Los Angeles, Calif. 90059 (USA).

20. Requests for reprints should be addressed to: R. E. Kauffman, M.D., Department of Pediatrics, University of Kansas School of Medicine, 39th and Rainbow Blyd., Kansas City, Kan., 66103 (USA).

21. Accepted for publication September 20, 1974.

Copyright (c) 1975 International Pediatric Research Foundation, Inc.

Printed in U.S..4.

Pediat. Res. 9: 107-110 (1975)

Distal latency time

full term infant

intrauterine growth retardation nerve transmission term infant

\title{
Acceleration of the Median Nerve Distal Latency Time in Preterm Infants with Intrauterine Growth Retardation
}

\author{
DONALD W. THIBEAULT, ${ }^{(13)}$ VIRGIL LAUL, AND HUBERT GULAK \\ Laboratory for Perinatal Research, Departments of Pediatrics and Physical Medicine, Harbor General \\ Hospital, UCLA School of Medicine, Torrance, California, USA
}

Extract

The distal latency time (DLT) of the median nerve was measured in infants at various stages of in utero and ex utero maturation.

The DLT measured at $36^{\circ}\left(\mathrm{DLT}_{36}\right)$ during the first 3 days of life was inversely related to gestational age in normal preterm infants. However, the DLT $_{36}$ was significantly accelerated in infants with in utero growth retardation (IUGR).

In normal infants the DLT $_{36}$ was significantly related to the nerve conduction velocity of the proximal segment of the median nerve. This relation was lost in infants with IUGR, since the $\mathrm{DLT}_{36}$ was accelerated but not the nerve conduction velocity.

In normal preterm infants the slope of change of $\mathrm{DLT}_{36}$ in utero with maturation was similar to the change ex utero. With IUGR the $\mathrm{DLT}_{36}$ shortened sharply during the first 2 weeks of postnatal life, and thereafter the $\mathrm{DLT}_{36}$ changed at the same rate as in normal infants.

The DLT is sensitive to temperature change in the thenar muscle. The more immature the infant the greater the change of DLT with temperature.

Apnea in preterm infants was not significantly related to the $\mathrm{DLT}_{36}$
Speculation

Intrauterine growth retardation accelerates the DLT of the median nerve but not the nerve conduction velocity of the proximal nerve. This study focused only on DLT changes with severe intrauterine growth retardation compared with normal preterm and term infants. Acceleration of the DLT may be a useful index of chronic stress in utero not associated with severe growth retardation.

The mechanism of apnea, a cornmon clinical complication in premature infants, is poorly understood. However, its frequent association with generalized muscle weakness suggests that interference with transmission of impulses in the neuromuscular junction may play a role. The neuromuscular junction in normal full term and large preterm infants operates with diminished reserves $(6,10)$, and in some respects resembles that of adult myasthenia gravis (2).

Nerve conduction velocities (NCV) in proximal peripheral motor nerves have been extensively studied and correlate significantly with gestational age, but are not influenced by multiple births or intrauterine and postnatal metabolic derangements (4-9). There has been only one study on the conduction time in the distal branches of the peripheral nerves (distal latency time (9), and this was with full term infants. It 